\title{
Pelatihan pemeriksaan payudara sendiri (Sadari) dalam upaya pemberdayaan masyarakat di Dusun Nyamplung lor Balecatur Gamping Sleman
}

\section{Self-examination of breast (SEB) training in efforts to empower the community in the hamlet of Nyamplung lor Balecatur Gamping Sleman}

\author{
Suyani ${ }^{1}$, Sri lestari ${ }^{2}$ \\ ${ }^{12}$ Universitas Aisyiyah Yogyakarta - Jalan Siliwangi No 63 Nogotirto Gamping Sleman \\ E-mail: suyanibasyar@unisayogya.ac.id/087739211688
}

Received: 31 September 2021; Revision: 15 Oktober 2021; Accepted: 05 November 2021

\begin{abstract}
Abstrak
Masih kurangnya pengetahuan masyarakat terhadap pengetahuan tentang SADARI (Periksa Payudara Sendiri). Masyarakat Nyamplung Lor Masih kental dengan budaya bahwa jika melakukan pemeriksaan akan ketahuan penyakitnya, Kehidupan masyarakat yang masih belum sadar akan pentingnya deteksi dini kanker payudara, Peran serta masyarakat masih kurang. Dengan masalah tersebut kegiatan yang kami lakukan adalah dengan mengadakan penyuluhan dan pelatihan terkait deteksi dini pada kanker payudara yaitu SADARI. Kegiatan pengabdian masyarakat ini bertujuan untuk meningkatkan pengetahuan tentang SADARI. Metode pelaksanaanya terbagi menjadi beberapa tahap yaitu tahap pertama koordinasi awal yaitu melakukan pendataan terkait jumlah anggota PKK yang ada di mitra melalui diskusi dengan pengurus PKK Nyamplung Lor. Tahap kedua Persiapan atau perencanaan terkait program. Menyusun media berupa leaflet dan video yang berisi tentang SADARI, selain itu menyusun waktu pelaksanaan program dimana mitra berperan menentukan jadwal kegiatan. Tahap ketiga pelaksanaan, Tahap keempat Evaluasi dilakukan setelah pelaksanaan program kegiatan. Hasil dari kegiatan pengabdian yang dilakukan pada bulan Agustus 2021 dengan peserta wanita usia subur (WUS) anggota PKK berjumlah 35 peserta. Pelaksanaan kegiatan penyuluhan dan pelatihan pemeriksan SADARI berjalan dengan lancar. Luaran kegiatan ini adalah memberdayakan peserta dengan meningkatkan pengetahuan tentang SADARI. Kesimpulan diharapkan ibu-ibu PKK dapat melakukan deteksi dini untuk kanker payudara dengan melakukan SADARI.
\end{abstract}

Kata Kunci: Pelatihan; SADARI; Ibu PKK

Abstract

Still lack of public knowledge of knowledge about Check Your Own Breasts. Nyamplung Lor community is still thick with culture that if the examination will be found out the disease, the lives of people who are still not aware of the importance of early detection of breast cancer, the role of the community is still lacking. With this problem, the activity we do is to conduct counseling and training related to early detection in breast cancer, namely Check Your Own Breasts. This community service activity aims to increase knowledge about Check Your Own Breasts. The implementation method is divided into several stages, namely the first stage of initial coordination, namely conducting data collection related to the number of PKK members in partners through discussions with PKK administrator Nyamplung Lor. The second stage of preparation or planning related to the program. Compiling media in the form of leaflets and videos that contain about SADARI, in addition to arranging the time of implementation of the program where the partner plays a role in determining the schedule of activities. The third stage of implementation, the fourth stage of evaluation is carried out after the implementation of the activity program. The results of the devotional activities conducted in August 2021 with female participants of childbearing age members of the PKK amounted to 35 participants. The implementation of counseling and training activities of SADARI examination went smoothly. The exterior of this activity is to empower participants by increasing knowledge about SADARI. It is expected that PKK mothers can make early detection for breast cancer by doing SADARI.

Keywords: Training; SADARI; PKK members

How to Cite: Suyani, S., \& lestari, S. (2021). Pelatihan pemeriksaan payudara sendiri (Sadari) dalam upaya pemberdayaan masyarakat di Dusun Nyamplung lor Balecatur Gamping Sleman. Masyarakat Berdaya dan Inovasi, 2(2), 144 - 149. doi:https://doi.org/10.33292/mayadani.v2i2.63 


\section{PENDAHULUAN}

Saat ini penyakit menular bukan lagi menjadi ancaman bagi masyarakat, akan tetapi penyakit non menular mulai mengkhawatirkan bagi masyarakat salah satunya kanker (Jannah, 2017)Penyebab utama kematian akibat kanker di seluruh dunia adalah kanker payudara, dengan hampir 1,7 juta kasus baru didiagnosis pada tahun 2012 yang mewakili sekitar 12\% dari semua kasus kanker baru dan 25\% dari semua kanker pada wanita (Rilyani \& Ellya, 2016). Kanker payudara merupakan keganasan yang bermula dari sel-sel di payudara (Yunita, 2019). Kanker payudara sendiri meningkat sesuai bertambahnya usia. Akan tetapi, usia muda juga bukan menjadi jaminan untuk aman dari kanker payudara (Jannah, 2017).

Angka kejadian kanker di dunia masih menduduki peringkat tertinggi setelah kardiovaskuler dan penyebab kejadian utama kematian. World Health Organization (WHO) mengatakan tahun 2018 insiden kanker payudara di dunia sebesar 2,09 miliar kasus dan 627.000 kasus kematian. Secara Nasional prevalensi penyakit kanker payudara di Indonesia sebesar 42,1 per 100.000 penduduk dengan rata-rata kematian 17 per 100.000 penduduk. Lalu di provinsi D.I.Yogyakarta sendiri memiliki prevalensi tertinggi untuk penyakit kanker, yaitu sebesar 4,86 per 1000 penduduk, dengan kanker tertinggi yang terjadi pada wanita adalah kanker payudara (Kemenkes RI, 2019).

Penyebab kanker payudara belum diketahui secara pasti karena termasuk multifaktorial, tetapi ada beberapa faktor yang mempunyai pengaruh besar yaitu riwayat keluarga, hormonal dan faktor eksogen (radiasi sinar x, virus dan zat kimia). Faktor-faktor lain meliputi umur, lokasi geografis dan ras, status perkawinan, paritas, riwayat menstruasi, berat badan dan penyakit payudara lain (Olfah, 2013). Penurunan angka kematian akibat kanker payudara dapat dipercepat dengan memperluas akses ke layanan pencegahan, deteksi dini, dan layanan pengobatan berkualitas tinggi untuk semua wanita (Carol et.al, 2019) . Sebaiknya pada wanita usia reproduktif harus diberikan penyuluhan tentang kanker payudara dan bagaimana mendeteksi secara dini (Kemenkes RI, 2019).

SADARI adalah pemeriksaan payudara sendiri yang bertujuan untuk mengetahui ada tidaknya kanker dalam payudara wanita. Kanker payudara masih mempunyai kemungkinan besar untuk disembuhkan jika ditemukan pada tahap awal atau dini (Olfah, 2013). Menurut penelitian (Beta, A.R, 2019) menyatakan pemeriksaan dini kanker payudara yang dapat dilakukan dengan mudah oleh perempuan di rumah serta tidak membutuhkan waktu lama, tidak membutuhkan biaya, terjaga privasinya dan bukan termasuk prosedur invasif.

SADARI sangat penting di masyarakat karena $86 \%$ benjolan dipayudara ditemukan oleh penderitanya sendiri. Akan tetapi kesadaran masyarakat untuk mendeteksi dini masih sangat rendah. Dikarenakan anggapan masyarakat bahwa penyakit kanker tidak bisa disembuhkan karena takut dengan hasil pemeriksaan. Selain itu mereka malu untuk melihat bagian tubuh dirinya didepan cermin. Sehingga hal tersebut merupakan hal penting bagi remaja untuk mengetahui tentang SADARI sedini mungkin. Karena semakin sering melakukan SADARI akan semakin mudah untuk menemukan sesuatu yang tidak normal pada payudara (Saryono \& Pramitasari, 2010). 
Studi Pendahuluan yang telah dilakukan di dusun Nyamplung Lor Balecatur Gamping berdasarkan hasil pengkajian data didapatkan bahwa kurangnya pengetahuan masyarakat terhadap pemeriksaan SADARI. Dari permasalahan tersebut maka untuk mencegah terjadinya Ca Mamae upaya yang dapat dilakukan adalah pemeriksaan SADARI (Periksa Payudara Sendiri).

\section{METODE}

Kegiatan pengabdian ini memberikan pengetahuan kepada ibu-ibu PKK tentang pemeriksaan SADARI melalui media leaflet, video dan di kuatkan melalui media zoom. Pelaksanaan pengabdian ini dilakukan melalui beberapa tahapan yaitu: tahap 1 koordinasi awal yaitu melakukan pendataan terkait jumlah anggota PKK yang ada di mitra melalui diskusi dengan pengurus PKK Nyamplung Lor. Tahap 2 : Persiapan atau perencanaan terkait program. Menyusun media berupa leaflet dan video yang berisi tentang pemeriksaan SADARI, selain itu menyusun waktu pelaksanaan program dimana mitra berperan menentukan jadwal kegiatan. Tahap 3: pelaksanaan kegiatan yang dilaksanakan pada bulan Agustus 2021. Peserta terdiri dari anggota PKK di Dusun nyamplung Lor yang berjumlah 35 peserta. Tahap 4 : Evaluasi dilakukan setelah pelaksanaan program kegiatan Bersama pengurus PKK dusun Nyamplung Lor Balecatur Gamping Sleman

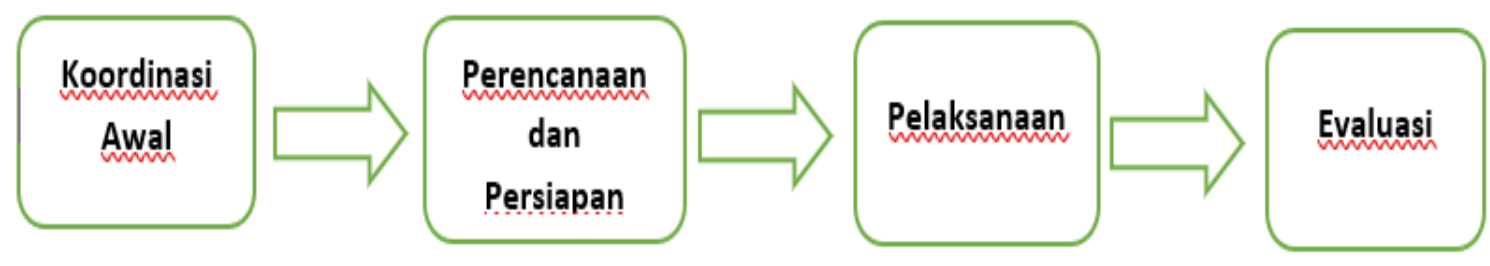

Gambar 1. Diagram Alur Pengabdian

\section{HASIL DAN PEMBAHASAN}

Bagian hasil dan pembahasan berisi temuan penelitian yang didapatkan dari data penelitian dan berkaitan dengan hipotesis serta diskusi hasil penelitian dan pembandingan dengan teori dan atau penelitian sejenis.

\section{Tahap 1: Koordinasi Awal}

Kegiatan koordinasi awal ini dilaksanakan di rumah ibu RW pada bulan Januari 2021. Dilakukan wawancara pada ibu ketua PKK dan pengurus terkait jumlaah anggota PKK saat ini yang aktif dan status pengetahuan secara umum tentang SADARI. Melalui wawancara itu didapatkan hasil bahwa jumlah anggota PKK yang termasuk wanita usia subur (WUS) berjumlah 69 peserta dan rata-rata belum mengetahui terkait pemeriksaan SADARI 


\section{Tahap 2 : Perencanaan dan Persiapan}

Perencanaan dan persiapan terkait program penyuluhan dan pelatihan pemeriksaan SADARI terdiri dari menyusun media penyuluhan beruba leaflet tentang materi pemeriksaan SADARI dan penyusunan video praktik pemerisksaan SADARI. Bersama mitra kami merencanakan jadwal program kegiatan. Pembuatan leaflet dan pembuatan video dilaksanakan pada bulan Maret 2021

\section{Tahap 3 : Pelaksanaan}

Pelaksanaan kegiatan program penyuluhan dan pelatihan pemeriksaan SADARI dengan sasaran peserta yaitu WUS yang menjadi anggota PKK di Dusun Nyamplung Lor Balecatur Gamping Sleman. Pelaksanaan kegiatan diawali dengan pembagian pembagian leafleat secara daring melalui grup PKK Dusun Nyamplung Lor Balecatur Gamping Sleman. Kemudian dilanjutkan dengan membagikan video praktek pemeriksaan SADARI.

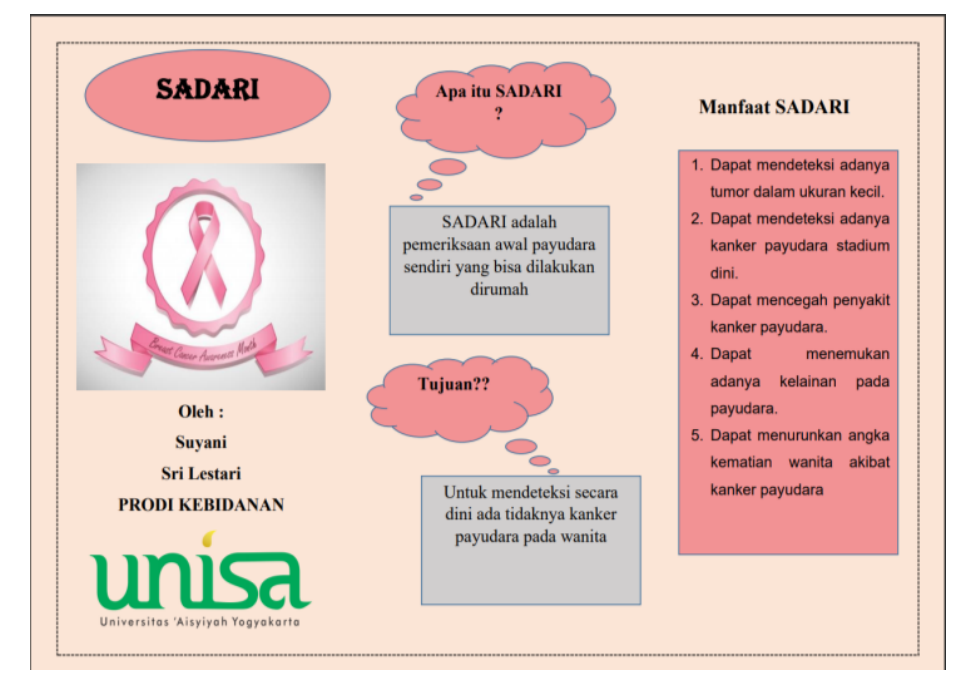

Gambar 2. Leaflet SADARI

Penggunaan leaflet dan video betujuan untuk menambah pengetahuan peserta tentang pemeriksaan SADARI seperti manfaat, kapan dilakukan dan tindak lanjut jika didapatkan hasil yang tidak normal. Terkait penggunaan media video bertujuan agar peserta dapat melihat langsung bagaimana prosedur pemeriksaan SADARI sehingga bisa langsung mempraktekkannya di rumah. Pembagian leaflet meski secara daring efektif untuk meningkatkan pengetahuan tentang pemeriksaan SADARI 


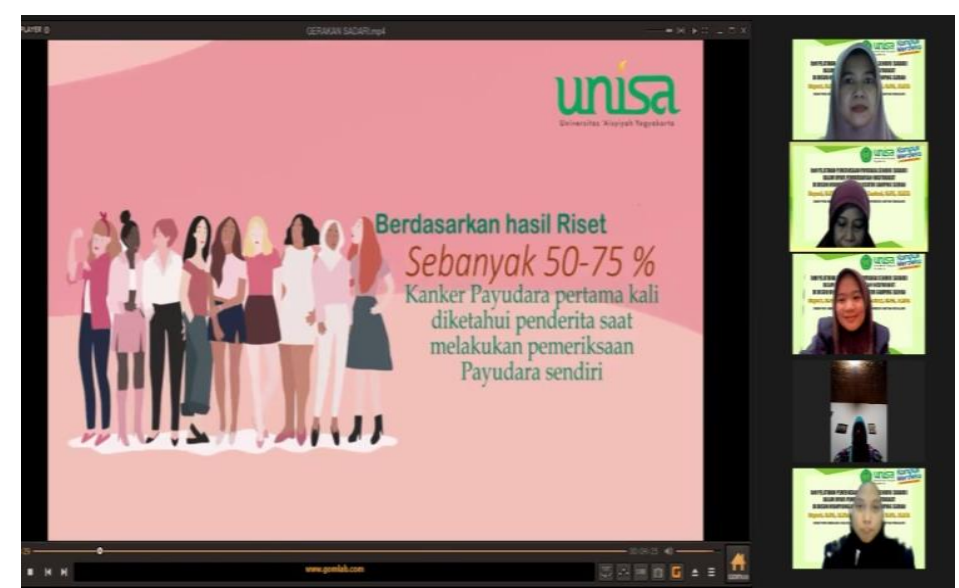

Gambar 3. Pemaparan materi saat pelatihan melalui media Zoom

Pelaksanaan kegiatan juga dilengkapi dengan kegiatan bertatap muka langsung menggunakan media zoom, dengan memberikan penguatan materi tentang pemeriksaan SADARI dan bagaimanacara pemeriksaan, dalam kegiatan ini pada sesi diskusi peserta sangat antusias terbukti dengan keaktifan peserta dalam mengikuti acara diskusi.

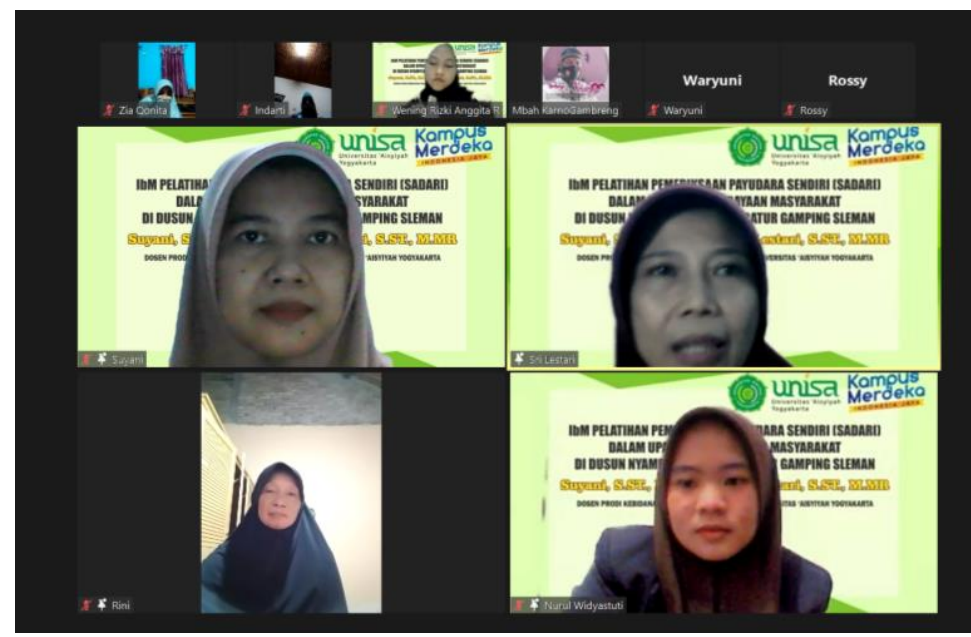

Gambar 4. Pelaksanaan diskusi saat pelatihan SADARI melalui zoom

\section{Tahap 4 : Evaluasi}

Melakukan evaluasi setelah pelaksanaan program kegiatan dengan melakukan wawancara terhadap ketua dan pengurus PKK di Dusun Nyamplung Lor Balecatur Gamping Sleman. Berdasarkan informasi yang disampaikan oleh para pengurus bahwa kegiatan ini sangat membantu pengurus PKK dan kader dalam memberikan pengetahuan kepada ibu-ibu PKK dalam rangka pemberdayaan diri untuk deteksi dini adanya penyakit kanker payudara kepada para peserta

\section{SIMPULAN}

Selama rangkaian kegiatan pengabdian masyarakat ini berjalan lancar meski terjadi penjadwalan ulang yang dikarenakan meningkatnya kasus Covid-19 di Yogyakarta. Dengan adanya kegiatan pengabdian masyarakat ini diharapkan ibu-ibu PKK dapat melakukan deteksi dini untuk kanker payudara dengan melakukan pemeriksaan SADARI di rumah. 


\section{UCAPAN TERIMA KASIH}

Kami menyampaikan terima kasih kepada LPPM Universitas Aisyiyah Yogyakarta yang telah membantu daalam pelaksanaan kegiatan pengadian ini, serta kepada pengurus PKK Dusun Nyamplung Lor Balecatur Gamping Sleman yang telah bekerjasama sebagai mitra pengabdian

\section{DAFTAR PUSTAKA}

Beta, A.R, dkk. (2019). Pengetahuan Dan Keterampilan Remaja Putri Mengenai Pemeriksaan Payudara Sendiri (SADARI) Knowledge And Skills Of Young Women Regarding Breast Self-Examinatio. Seminar Nasional Keperawatan "Penguatan Keluarga Sebagai Support Sysstem Terhadap Tumbuh Kembang Anak Dengan Kasus Paliatif" Tahun 2019.

Carol et.al. (2019). Breast Cancer Statistic. A Cancer Journal for Clinicians, 69(6), 438-451.

Jannah. (2017). Tingkat Pengetahuan Remaja Puteri Tentang SADARI Dalam Upaya Deteksi Dini Kanker Payudara Di Pondok Pesantren Addainurriyah II Semarang. Jurnal Dinamika Kesehatan, $1(8), 2-3$.

Kemenkes RI. (2019). Hari Kanker Sedunia. https://www.depkes.go.id/article/view/19020100003/harikanker-sedunia-2019.html.

Olfah, D. (2013). Kanker Payudara \& SADARI (pertama). Nuha Medika.

Rilyani \& Ellya, R. (2016). Pengaruh Penyuluhan Kesehatan Terhadap Keterampilan Remaja Putri Dalam Melakukan Sadari Sebagai Upaya Deteksi Dini Kanker Payudara. Jurnal Kesehatan Holistik (The Journal of Holistic Healthcare), 2(10), 1-4.

Saryono \& Pramitasari. (2010). Perawatan Payudara. Nuha Medika.

Yunita, I. (2019). Stop Kanker. Agromedia Pustaka. 